\title{
Dietary Step-Down Protein with Addition of Acidifier to Improve Productive Effciency of Broiler Chickens
}

\author{
Mahfudz, L. D*, T. A. Sarjana, E. Suprijatna, B. Ma'rifah, N. Suthama
}

Faculty of Animal and Agriculture Science, Diponegoro University Semarang 50275, Central Java, Indonesia

DOI: $10.36347 /$ sjavs.2020.v07i07.005

| Received: 13.07.2020 | Accepted: 21.07.2020 | Published: 28.07.2020

*Corresponding author: Mahfudz, L. D

\section{Abstract}

Original Research Article

The purpose of this research was to improve the productive efficiency of broiler chickens through feeding single stepdown protein diet, without interferring with either the process of digestionornutrientabsorption, and lowering production costs. The present research was assigned in a completely randomized design with 6 treatments and 4 replications. Each replication consisted of 8 birds of one-week old broiler. Treatment applied were P0(control diet without step-down protein and acidifier), P1(step-down protein without acidifier), P2(step-down protein $+0.8 \%$ citricacid), P3(step-down protein $+0.4 \%$ lime juice), P4(step-down protein $+0.8 \%$ lime juice), and P5 (step-down protein $+1.2 \%$ lime juice). The parameters measured were the performances (feed consumption, body weight, and feed conversion ratio/FCR), muscle protein mass, and protein and energy efficiency). The data were subjected to analysis of variance with $F$ test to determine the effect of treatment, when the treatment indicated significant effect, it was continued to Duncan test. Results showed that the highest feed consumption was found in chickens fed dietarystepdown protein without acidifier $(\mathrm{P} 1)$, and it was significantly different $(\mathrm{P}<0.05)$ from that given dietary step-down protein with additional acidifier of $1.2 \%$ (P5). However, body weight, and FCR of P5 were the highest and significantly $(\mathrm{P}<0.05)$ different as compared to $\mathrm{P} 1$. Similarly, the most efficient protein and energy utilization were also found in P5. In conclusion, the productive efficiency of broiler chickenscan be improved by dietary inclusion of $0.8 \%$ citric acid as acidifier into step-down protein diet.

Keywords: Productive efficiency, dietary step-down protein, acidifier, broiler.

Copyright @ 2020: This is an open-access article distributed under the terms of the Creative Commons Attribution license which permits unrestricted use, distribution, and reproduction in any medium for non-commercial use (NonCommercial, or CC-BY-NC) provided the original author and source are credited.

\section{INTRODUCTION}

Broiler industry grows very fast in one side, but in other side, it recently is facing on lack and expensive feedstuff, which bring about the increase in production cost. Considering the cost for feed is covering about $70-80 \%$ of total production cost for broiler chicken, it reliable to find an alternative strategy in feed formulation in order to decrease feed cost. Feed price in poultry production systemic absolutely dependent on protein source used in the diet formulation, the higher dietary protein content the more expensive price of the diet. However, lowering dietary protein sourcecould ensure the price of diet is getting lower. Decreasing protein content of the diet (step down) is one strategy can be possible to decrease feed price and also nitrogen emission. Those two impacts due to the lower dietary protein content can further increase efficiency of broiler production with environmental friendly. However, decreasing protein diet level (step down) is apprehensive about insufficient protein supply for broiler, and it would be more pronounced when step down protein is provided at theearly stage (starter period). Therefore, to overcome the negative impact of feeding step down dietary protein, the strategy will possibly beneficial when it combined with non-interfere supplemental substance such as acidifier.

Acidifier is an organic acid of either natural or synthetic that can have beneficial effect onprotection feed from destroying of harmfulbacteria and fungi, thusit can be expected to help and support the increase infeed digestibilityand nutrients absorption. The physiologicalmechanism of providing acidifier is in connection with indirect effect in increasing digestibility via decreasing intestinalpH and reduction of pathogen microorganism and/or gram negative bacteria. Acidifier can modulate the gastro intestinal tract $\mathrm{pH}$ with a decrease in gastric $\mathrm{pH}$, and increase the conversion of pepsinogen into pepsin which serves to improve the rate of absorption of protein, amino acids and minerals. The increase in nutrients digestibility due to feeding effect of organic acids has been reported previously. For example, Hernandez et al., [1] reported 
that the dietary addition of formic acid $(10 \mathrm{~g} / \mathrm{kg}$ of feed) improved the digestibility of dry matter (ileal digestibility) in broilers. Another study conducted by Jamilah et al., [2] indicated that dietary addition of $0.8 \%$ citric acid was considered to be potential in broiler performance improvement via the increase in protein deposition. Ghazalah et al., [3] reported that addition of $0.5 \%$ formic acid can be used to encourage the performance of broiler. It was further stated that the ideal dose of dietary inclusion of commercial acidifier was between 0.2 and 1\%. Lückstädt et al., [4] and Cengiz et al., [5] shown that strategic interaction between formic acid and propionic acid with organic silica as carrier (standard dose was $3 \mathrm{~kg} /$ ton of diet) had significant effect to encourage growth of broiler chicken until 35 days of rearing period.

As it has been described previously that the positive effect of feeding acidifier is in relation to the controlling the balance of microorganism in the digestive tract which further can help to stimulate digestive enzymes work for the increase in nutrients digestibility and performance of poultry. Optimizing digestive tract function, as a way to improve nutrition absorption, is an important factor to maintain the maximum production. In the past decade, antibiotic in some ways, have been very popular to be used to regulate pathogen microorganism and also function as growth promoter to improve productive efficiency. However, providing antibiotic to the farm animals nowadays has been banned worldwide due to some negative effects such as the resistance of certain bacteria, and also build a residue in animal products which is not consumer health friendly [6]. Some substances, such as pro- and prebiotic, organic acid, essential oil, and plant extract, are greatly possible as natural sources of feed additive to be alternatively replaced the function of antibiotic. Providing acidifier is an alternative way to solve the problem of feeding antibiotic in livestock. Concept of integrating effect of acidifier and feed manipulation as described above can be function of an alternative replacement for antibiotic as growth promoter in poultry, especially broiler chickens.

Based on the problems and background described above, the study concerning the decrease in dietary protein has been conducted at the starter period only, by providing the low protein diet (single step down protein) combined with the addition of lime juice and commercial citric acid as natural and synthetic acidifier, respectively. Improving efficiency of feed utilization and lowering the feed price were the main purpose of the present research. The strategy of feeding management and manipulation in broiler was focused on the positive balance between input and output in order to obtain maximal revenues.

\section{MATERIAL AND METHOD Experimental Animal and Ration}

The experimental animals were 192 birds of 1 week old broiler, with an initial body weight was $224.51 \pm 1.63 \mathrm{~g}$. Broilers were maintained for 1 week in a brooder cageprior to grouping for treatments, and provided a commercial feed (BR 1A). The uniform body weight was selected and randomly divided into 6 groups of treatment thereafter. During feeding trial, broilers were reared in colony cages, containing 8 birds each, equipped with feeder box and plastic bowl for drinking water.Experimental diet was composed of yellow corn, rice bran, vegetable oil, fish meal, soybean meal, $\mathrm{CaCO} 3$, oyster shell, vitamins and minerals, and amino acids (lysine and methionine). Diet for starter period was prepared by decreasing protein content from $21 \%$ to $19 \%$ (single step-down) similar to that for finisher (19\% protein) but with iso-energy (Table-1). Two sources of citric acid were used in the present study, namely synthetic citric acid and natural source derived from lime juice. The content of citric acid of lime juice was analyzed prior to treatment to determine the supplementation dose. Feeding trial was started from day 8 and completed when the birds were 5 weeks old.

Experimental Design, Parameters and Statistical Analysis

Experiment was assigned in a completely randomized design (CRD) with 6 treatments and 4 replications, and totally there were 24 experimental unitscontaining 8 birds each.

Experimental treatments were as follows:

$\mathrm{P}_{0}$ : Control feed (without step down protein and citric acid)

$\mathrm{P}_{1}$ : Step down protein without citric acid

$\mathrm{P}_{2}$ : Step down protein + citric acid $0,8 \%$ (synthetic form)

$\mathrm{P}_{3}$ : Step down protein + lime juice $0,4 \%(6,9 \mathrm{ml} / 100 \mathrm{~g}$ feed $)$

$\mathrm{P}_{4}$ : Step down protein + lime juice $0,8 \%(13,8 \mathrm{ml} / 100 \mathrm{~g}$ feed $)$

$\mathrm{P}_{5}$ : Step down protein + lime juice $1,2 \%(20,7 \mathrm{ml} / 100 \mathrm{~g}$ feed)

Parameters observed in the present study were growth performance (feed consumption, body weight, and feed conversion ratio), muscle protein mass (\% muscle protein multiplied by weight of muscle), and protein and energy efficiency (protein and energy consumption divided by muscle protein mass). The last three parameters were calculated as described by Suthama [7]. Data were statistically analyzed by analysis of variance, and it was followed by Duncan multiple range test at $5 \%$ probability level [8] when the treatment indicated significant effect. 
Table-1: Feed Composition and Nutritional Content

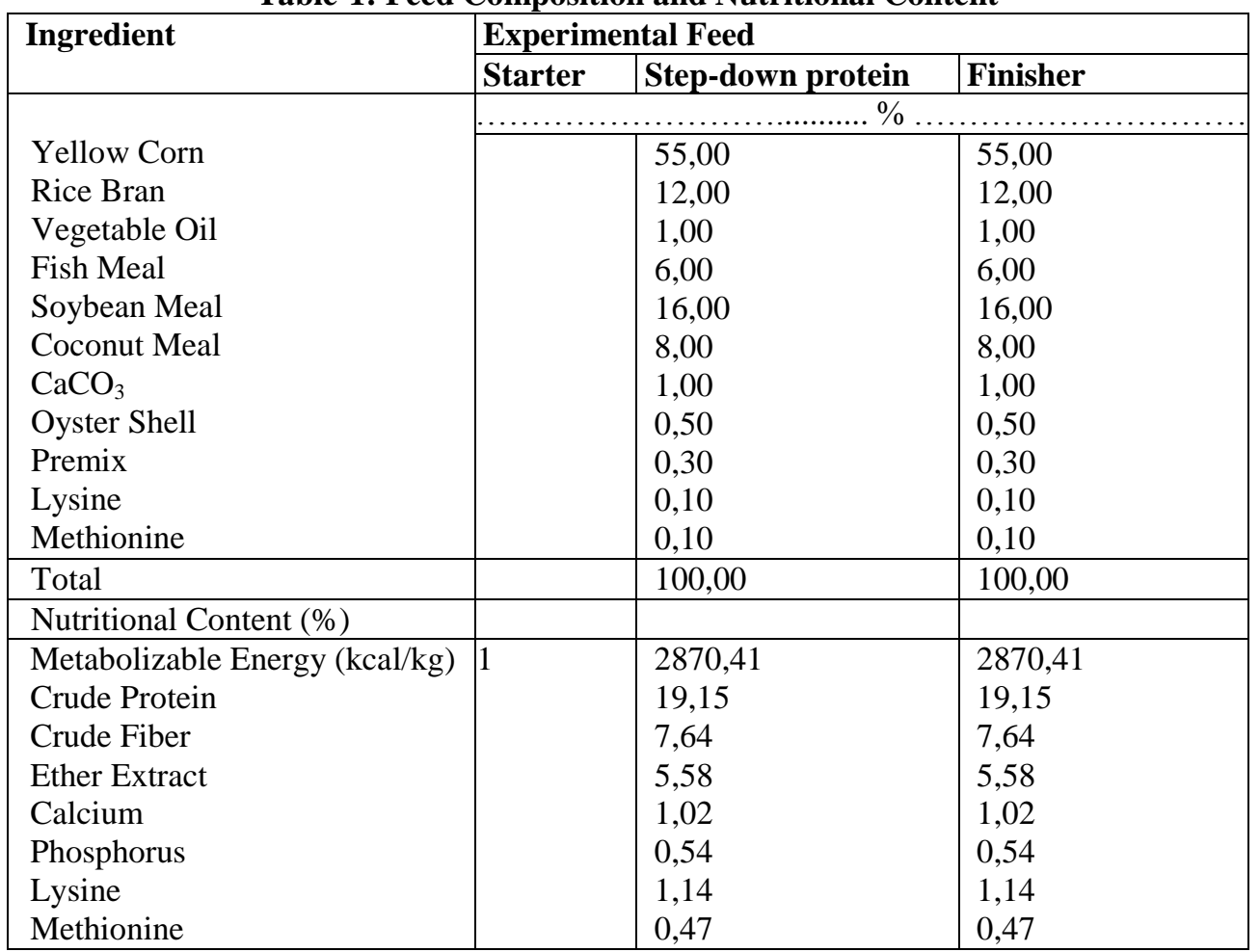

*Feed ingredients wereanalyzed at the Laboratory of Animal Nutrition and FeedScience, Faculty of Animal and Agriculture Science, Diponegoro University

\section{RESULTS AND DISCUSSION Growth Performance}

Feed consumption increased significantly $(\mathrm{P}<0.05)$ when dietary step-down protein without acidifier (P1) was fed as compared to control birds (P0). However, the significant decreased in feed consumption was found in birds fed step-down protein diet with highest level of supplemental lime juice (P5) compared to $\mathrm{P} 0, \mathrm{P} 1, \mathrm{P} 2$, and $\mathrm{P} 4$, but no difference with $\mathrm{P} 3$ (Table$2)$. Although body weight of P5 indicated the highest value, it only significantly different $(\mathrm{P}<0.05)$ to that of $\mathrm{P} 0$, but among other treatments were statistically not different. It seems to show similar pattern of feed conversion ratio with feed consumption of $\mathrm{T} 1$ was the highest value and it was significantly higher $(\mathrm{P}<0.05)$ than those of P0 and P5. In case of treatments P2 and $\mathrm{P} 5$ in which lowered dietary protein was providedbut together with the inclusion of acidifier brought about thesamebody weightcompared to P0 (normal diet).

Growth mechanism which is supported by nutritional metabolism is normally related to the enviromental condition. However, maintaining broiler in hot condition or tropical climate, especially that with open house system, feeding management should be strictly considered in relation to the physiologically body load due to unfavourable environment. High ambient temperatures caused lower feed intake and result poor growth or low body weight as it was found in broilers fed normal dietary protein (P0). Hot enviromental temperature leads to the change in hormonal status via the inhibition of growth hormone
(GH) and/or thyroid hormone productions, and brought about the disruption of the body's metabolic system. It has been reported that the condition of hot temperature reduced or inhibited production of thyroid stimulating hormone/TSH [9], and decreased plasma concentration of triiodothyronine (T3) in broiler chickens [10, 11]. Production of T3 is activated by TSH via a negative feedback mechanism of the pituitary. Circulating blood concentration of $\mathrm{T} 3$ is regulated by reducing the deactivation of growth hormone $(\mathrm{GH})$. This phenomenom leads to a decrease in growth, both body weight and bone, especially in young chickens [12]. The physiological condition as described above could be precisely occurred in $\mathrm{P} 0$ eventhough the birds were given normal protein diet.

On the other hand, low protein diet (step-down protein) with inclusion of lime juice of $20.7 \mathrm{ml} / 100 \mathrm{~g}$ feed (equivalent to $1.2 \%$ citric acid/P5), produced higher final body weight as compared to normal diet without acidifier/P0 (Table-2). This indicated that acidifier was beneficial to support the improvement of birds performance when they were reared in the tropical region, such as Indonesia. As it might be known that birds maintained at a high ambient temperature absolutely need more supply of antioxidant, in a form of vitamin C. Therefore, acidifier is assumed to have beneficial effects on the enhancement of effectiveness of vitamin $\mathrm{C}$ activity when the enviromental temperature higher that thermoneutral zone $\left(28-37^{\circ} \mathrm{C}\right)$. It could be explained that acidifier served to be a double functions additive, first, its relationship with vitamin C 
function as described above, and second, increased the efficiency of amino acid utilization by improving the digestibility due to the improvement of the intestinal microflora balance. Kurniagung et al., [13] reported that the addition of lime juice with citric acid content of 1.5 to $4.5 \mathrm{ml}$ lowered the $\mathrm{pH}$ to be 5.0 , and this contributes to the increase in the number of lactic acid bacteria (LAB) ranged from 950 to $1650 \mathrm{CFU} / \mathrm{ml}$. On the other hand, low $\mathrm{pH}$ resulted in a decrease in total coliform bacteria in the digestive tract (duodenum, jejunum, ileum), which is an indicator of the health status of the animal. Feeding acidifier could suppressed gastrointestinal pathogenic bacteria due to the low $\mathrm{pH}$, and in other side, increased population of beneficial bacteria for the host [2]. The balance improvement of bacteria causes the higher gastrointestinal health status of the birds and stimulate the better villi growth to broaden the absorptive suface. This condition giving an impact on the improvement of nutrients utilization efficiency, especially protein and finally resulted the increase in body weight.

The conventional theory describes that the higher feed intake the better growth or body weight can be achieved. The present result, especially treatment of P5, was precisely the opposite of the usual theory that the decrease in feed consumption resulted the higher body weight. The beneficial effect of acidifier, as described previously, was on the improvement of intestinal condition so that nutrients digestibility increased although with lower intake. According to the studies of Abdel-Fattah et al., [14], Kopecky et al., [15], and Lückstädt [16] that dietary inclusion of citricaciddecreasedfeed consumptionof broilers. It is intresting that when protein content of feed lowered, with lower consumption, however, acidifiers did help to maximize the absorption of nutrients in order that no protein deficiency occured. This is in accordance with the report of Natsir [17] that administration of an organic acid (acidifier) can improved the microbial balance in the digestive tract by maintaining low $\mathrm{pH}$ and promoted to increase protein absorption.Although the birds were given low protein diet, it can be assumed that acidifier inclusion was able to overcome the possibility of protein intake lacking otherwise the supply of protein could be maintained. This phenomenon indicated that the efficiency of protein utilizationcan be enhanced by the inclusion of acidifier similar to that ofP0 (Table-2). Kopecky et al., [15] stated that broilers fed diet with supplemental organic acids could improve nutrient utilization, feed efficiency, and growth. A moderate improvement of body weight was found in the treatments of P2 until P4 similar to those in P0 and P5 (Table-2). This also due to the work of acidifier to enhance the efficiency of protein utilization considering that feed consumptions were all lower than P0, except P1 resulted the same body weight becausethe increase in feed consumption can be assumed to contribute the higher protein intake. According to Kamal and Ragaa [18] that the amount of feed consumed related to the nutrient sentering the body, easpecially protein which is supporting growth or body weight. Furthermore, feeding organic acid as feed additives improved growth performance of broilers through their physiological action involving activities some endogenous mechanisms such as metabolic substances with the beneficial antimicrobial effect which may be responsible for better performance or growth. Previous results reported by Yakhkeshi et al., [19] that acidifier caused higher efficiency of nutrients utilization and led to the better performance in broilerdue to the improvement of the gut microflora balance by producing appropriate $\mathrm{pH}$ and reducing harmful bacteria. Similarly, Dehghani and Jahanian [20] stated that the additional levels of citric acid at $0.25 \%$ and butyric acid at $0.25 \%$ had a positive effect on growth (weight gain), feed intake and feed efficiency in broiler chicken

The increased feed intake, such as in P1 (whithout acidifier), brought about the significantly higherfeed consumption with unchanged body weight, and consequencyly feed conversion ratio (FCR) significantly increased as compared to P0 (Table-2). The spesific phenomenon found in the present study is that when citric acid was added into the low dietary protein (step-down protein) either natural (lime juice) or synthetic sources (P2 until P4), slighly lowered feed consumption with slightly increased body weight, thus FCR can be categorized to improve as mediumvalue. The low FCR in P5, and significantly lower than P1, because feed consumption was the lowest and body weight was the highest due to dietary inclusionof lime juice as acidifier. However, FCRvalue found in the present study which ranged between 1.62 to 1.98 were in accordance with the previous study of Angel et al., [21] who reported that FCR value in broiler ranged from 1.66 to 1.82. Citric acid is assumed to be able to increase feed efficiency or improved nutrients utilization, so that the same feed consumption (P2 until P5) resulted body weight similar to the control (P0), as it has been discussed previously. According to Runho et al., [22], Houshmand et al., [23] and Jamilah et al., [2] stated that the inclusion of acidifiercould increased intestinal health via the improvement of gut bacteria balance and brought about better growth of the intestinal villi, thus increasing the absorptive surface for nutrients. Similar results was also reported by Adil et al., [24] that organic acid supplementation could improve nutrients utilization resulting higher body weight gain and finally lowered feed conversion ratio.

\section{Muscle Protein Mass and Efficiency}

Muscle protein mass was the end point of performance product, which demonstrated a different results when dietary step-down protein with increasing levels of citric acid were offered.Dietary inclusion of citric acid both natural (lime juice) as well as synthetic sourcesincreased muscle protein mass significantly $(\mathrm{P}<0.05)$ to be higher than that of control diet $(\mathrm{P} 0)$. It is 
important to understand that the lower values of either energy or protein efficiency the more efficient for those two nutrients used for protein deposition (Table-2). Energy and protein supplies for use in the protein deposition (muscle protein mass) indicated the lower values with the higher levels of supplemental acidifier. It can be known that P2, P3 and P5 were significantly lower compared to P0 and P1 for energy efficiency, and
P2 and P5 were lower than P0 and P1 for protein efficiency (Table-2). This phenomenon provides a meaning that the higher protein deposited in the muscle, the lower amount of energy and protein supply needed, otherwise, the amount of energy and protein contributions were lower for the increase in one unit deposited proteinwhen the birds were given higher levels of acidifier.

Table-2: Growth Performance, andEnergy and Protein Efficiency ofBroiler Chickens Fed Dietary Protein Step Down With Supplemental Acidifier

\begin{tabular}{|l|l|l|l|l|l|l|}
\hline Treatments & \multicolumn{9}{|c|}{ Parameters } \\
\cline { 2 - 7 } & $\begin{array}{l}\text { Feed } \\
\text { Consumption } \\
\text { (g/bird) }\end{array}$ & $\begin{array}{l}\text { Body } \\
\text { Weight } \\
\text { (g/bird) }\end{array}$ & $\begin{array}{l}\text { Feed } \\
\text { Conversion } \\
\text { Ratio }\end{array}$ & $\begin{array}{l}\text { Muscle Protein } \\
\text { Mass } \\
\text { (g/bird) }\end{array}$ & $\begin{array}{l}\text { Energy } \\
\text { Efficiency }\end{array}$ & $\begin{array}{l}\text { Protein } \\
\text { Efficiency }\end{array}$ \\
\hline P0 & $2,041.01^{\mathrm{bc}}$ & $1100,50^{\mathrm{b}}$ & $1.62^{\mathrm{b}}$ & $79,18^{\mathrm{d}}$ & $74.81^{\mathrm{a}}$ & $5.02^{\mathrm{a}}$ \\
\hline P1 & $2,272.52^{\mathrm{a}}$ & $1245,00^{\mathrm{ab}}$ & $1.98^{\mathrm{a}}$ & $88,64^{\mathrm{c}}$ & $74.37^{\mathrm{a}}$ & $4.91^{\mathrm{ab}}$ \\
\hline P2 & $2,125.31^{\mathrm{ab}}$ & $1286,25^{\mathrm{ab}}$ & $1.78^{\mathrm{ab}}$ & $100,20^{\mathrm{a}}$ & $61.55^{\mathrm{b}}$ & $4.07^{\mathrm{b}}$ \\
\hline P3 & $2,057.02^{\mathrm{bc}}$ & $1303,00^{\mathrm{ab}}$ & $1.78^{\mathrm{ab}}$ & $93,08^{\mathrm{bc}}$ & $64.14^{\mathrm{b}}$ & $4.23^{\mathrm{ab}}$ \\
\hline P4 & $2,200.05^{\mathrm{ab}}$ & $1297,25^{\mathrm{ab}}$ & $1.83^{\mathrm{ab}}$ & $95,11^{\mathrm{b}}$ & $67.09^{\mathrm{ab}}$ & $4.43^{\mathrm{ab}}$ \\
\hline P5 & $1,994.68^{\mathrm{c}}$ & $1383,50^{\mathrm{a}}$ & $1.67^{\mathrm{b}}$ & $92,47^{\mathrm{bc}}$ & $62.63^{\mathrm{b}}$ & $4.13^{\mathrm{b}}$ \\
\hline
\end{tabular}

Note: Different superscripts in the same column indicate significant difference $(\mathrm{P}<0.05)$

Health status is one related factor that determines the efficiency and effectiveness of protein and energy utilization for body protein deposition (muscle protein mass).Supplemental acidifierassociated health status is started from the impact of intestinal condition as reported by Houshmand et al., [23] and Jamilah et al., [2]. Higher health condition and better growth of intestinal villi needed less proteins for use of tissue repair as well as antibody-formation, and consequently economizing protein utilization for whole body protein deposition. The present study indicated that the lower values of protein and energy efficiency the higher protein deposited into the muscle. Table-2 showed that acidifier suplementation (P2, P3 and P5) significantly improvedto energy and protein efficiency, indicated by lower values, than treatment without acidifiers (P0 and P1). The better efficiency of energy and protein was supported by the increased protein digestibility under the effect of acidifier although dietary protein was lowered (step-down protein). The increase in protein digestibility, which is closely related to the efficiency of protein for body protein deposition, was found to be attributable to the dietary citric acid inclusion [25]. Acidic conditions of the digestive tract supports the action of enzymes, such as pepsin digestion, which serves the increase in the rate of digestion and absorption of protein and energy in the proventriculus and gizzard, and proteolytic enzymes (trypsin and chemotripsin) in the small intestine to produce peptides and amino acids. Kim et al., [26] described that acidifier citric acid at $1 \%$ lowered the $\mathrm{pH}$ from 4.6 to 3.5 and fumaric acid at $0.7 \%$ reduced the $\mathrm{pH}$ from 4.6 to 4.2 in the gastrointestinalof broiler chickenwhich can induced an increase in enzyme activity.
The most interesting result is that muscle protein deposition (muscle protein mass) was the highest among other treatments supported by the better energy and protein efficiency (Table-2) when low protein diet (step-down protein) added with $0.8 \%$ synthetic citric acid (P2), even feed consumption and body weight were medium. This is clear that a siutable acidifier at an appropriate level had an important role in body protein metabolism with reduced protein diet,but protein deposition (muscle protein mass) was maintained high. Muscle protein mass increased if the rate of protein synthesis exceded protein breakdown [27]. This is in accordance with Mahfudz et al., [28] that dietary protein deposited into the muscle at a higher rate when protein input of absorbed and utilized protein by the body exceded the output. Broiler with better health status used less protein to repair damaged tissue and antibody formation, therefore, protein deposited into the muscle was high. On the other hand, the lower health status in birds fed diet without acidifier was evidenced by high weights of bursa and spleen [2]. In case of muscle protein deposition either related to acidifier or not, Suthama [29] described that the protein deposition ability of the birds is the important determinant for productive quality of poultry farming. The higher muscle protein deposition (muscle protein mass) the better carcass quality of broiler can be achieved due to feeding low protein diet (step-down protein), and supported by the lower energy and protein expenditures as indicated by the values of energy and protein efficiency. 


\section{CONCLUSION}

Dietary inclusion of citric acid improves body weight and muscle protein mass with the minimal use of energy and protein and $0.8 \%$ synthetic citric acid can be categorized as the optimal level.

\section{REFERENCES}

1. Hernández F, López M, Martínez S, Megías MD, Catalá P, Madrid J. Effect of low-protein diets and single sex on production performance, plasma metabolites, digestibility, and nitrogen excretion in 1-to 48-day-old broilers. Poultry Science. 2012 Mar 1;91(3):683-92.

2. Jamilah NS, Mahfudz LD. Performa produksi dan ketahanan tubuh broiler yang diberi pakan step down dengan penambahan asam sitrat sebagai acidifier. JITV. 2013;18(4):251-7.

3. Ghazalah AA, Atta AM, Elkloub K, Moustafa ME, Riry FH. Effect of dietary supplementation of organic acids on performance, nutrients digestibility and health of broiler chicks. International Journal of Poultry Science. 2011;10(3):176-84

4. Lückstädt C, Şenköylü N, Akyürek H, Aĝma A. Acidifier--a modern alternative for anti-biotic free feeding in livestock production, with special focus on broiler production. Veterinarija ir zootechnika. 2004 Sep 1;27(49):91-93.

5. Cengiz O, Koksal BH, Tatli O, Sevim O, Avci H, Epikmen T, Beyaz D, Buyukyoruk S, Boyacioglu M, Uner A, Onol AG. Influence of dietary organic acid blend supplementation and interaction with delayed feed access after hatch on broiler growth performance and intestinal health. Veterinarni Medicina. 2012 Oct 1;57(10):515-528.

6. Stein RA. Antibiotic resistance: A global, interdisciplinary concern. The american biology Teacher. 2011 Aug;73(6):314-21.

7. Suthama N. Kajian aspek protein turnover tubuh pada ayam Kedu periode pertumbuhan. Media peternakan. 2006;29(2):47-53.

8. Steel RGD, Torrie JH. Prinsip dan Prosedur Statistika: Suatu Pendekatan Biometrik. Cetakan kedua. PT. Gramedia Pustaka Tama. Jakarta. 1995.

9. Akter S, Khan MZ, Jahan MR, Karim MR, Islam MR. Histomorphological study of the lymphoid tissues of broiler chickens. Bangladesh Journal of Veterinary Medicine. 2006;4(2):87-92.

10. Darras VM, Van der Geyten S, Kühn ER. Thyroid hormone metabolism in poultry. BASE. 2000 Jan 1 ; 4(1):13-20.

11. Lara LJ, Rostagno MH. Impact of heat stress on poultry production. Animals. 2013 Jun;3(2):35669.

12. Mahfudz LD, Maulana FL, dan Atmomarsono U, Sarjana TA. Karkas dan Lemak Abdominal Ayam Broiler yang Diberi Ampas Bir Dalam Ransum. Seminar Nasional Kebangkitan Peternakan, 20 Mei 2009, Semarang. 2009.
13. Kurniagung F, Ismadi VD, Estiningdriati I. Pengaruh penambahan jeruk nipis (Citrus aurantifolia) dalam ransum terhadap total bakteri asam laktat dan bakteri coliform pada saluran pencernaan itik magelang jantan. Animal Agriculture Journal. 2012;1(1):417-25.

14. SA AF, El-Sanhoury MH, El-Mednay NM, AbdelAzeem F. Thyroid activity, some blood constituents, organs morphology and performance of broiler chicks fed supplemental organic acids. International journal of poultry science. 2008;7(3):215-22.

15. Kopecký J, Hrnčár C, Weis J. Effect of organic acids supplement on performance of broiler chickens. Scientific Papers Animal Science and Biotechnologies. 2012;45(1):51-4.

16. Lückstädt C. Effects of dietary potassium diformate on growth and gastrointestinal health in weaned piglets in Vietnam. InConference on International Research on Food Security, Natural Resource Management and Rural Development organized by the Czech University of Life Sciences Prague 2014 Sep (pp. 17-19).

17. Natsir MH. Pengaruh penggunaan kombinasi asam sitrat dan asam laktat cair dan terenkapsulasi sebagai aditif pakan terhadap persentase karkas dan berat organ dalam ayam broiler. J Ilmu Teknol Hsl Ternak. 2008;3(2):17-22.

18. Kamal AM, Ragaa NM. Effect of dietary supplementation of organic acids on performance and serum biochemistry of broiler chicken. Nature and Science. 2014;12(2):38-45.

19. Yakhkeshi S, Shawrang P, Rahimi S. Effect of some acidifiers on gastrointestinal tract characteristics and performance of broiler chickens. Iranian J App Anim Sci. 2014;4(1):143149.

20. Dehghani N, Jahanian R. Interactive Impacts of Dietary Organic Acid and Crude Protein Level on Performance and Gut Morphology of Broiler Chicken. Journal Word Poltry. 2012;3:345-53.

21. Angel R, Dalloul RA, Doerr J. Performance of broiler chickens fed diets supplemented with a direct-fed microbial. Poultry Science. 2005 Aug 1;84(8):1222-31.

22. Runho RC, Sakomura NK, Kuana S, Branzatto D, Junqueira OM, Stringhini JH. Uso do acido organico (acido fumarico) nas racoes de frangos de corte. Rev Bras Zootec. 1997; 26:1183-1191.

23. Houshmand M, Azhar K, Zulkifli I, Bejo MH, Kamyab A. Effects of non-antibiotic feed additives on performance, immunity and intestinal morphology of broilers fed different levels of protein. South African Journal of Animal Science. 2012;42(1):23-32.

24. Adil S, Banday T, Ahmad Bhat G, Salahuddin M, Raquib M, Shanaz S. Response of broiler chicken to dietary supplementation of organic acids. Journal of Central European Agriculture. 2011 Nov 8;12(3):498-508. 
25. Saputra WY, Suthama N, Mahfudz LD. Pemberian kombinasi pakan double step down dan asam sitrat sebagai upaya peningkatan efisiensi usaha peternakan broiler. Buletin Nutrisi dan Makanan Ternak. 2016 Aug 11;10(1):34-40.

26. Kim YY, Kil DY, Oh HK, Han IK. Acidifier as an alternative material to antibiotics in animal feed. Asian-Australasian journal of animal sciences. 2005 Nov 26;18(7):1048-60.

27. Suthama N. Mechanism of Growth Promotion Induced by Dietary Thyroxine in Broiler Chickens.
Kagoshima University, Kagoshima, Japan (PhD. Dissertation). 1991.

28. Mahfudz LD, Hayashi K, Nakashima K, Ohtsuka A, Tomita Y. A growth promoting factor for primary chicks muscle cell culture from shochu distillery byproduct. J. Biosecience, Biotechnology and Biochemistry. 1997:715-20.

29. Suthama N. Pakan Spesifik Lokal dan Kualitas Pertumbuhan untuk Produk Ayam Lokal Organik (Pidato Pengukuhan). Badan Penerbit Universitas Diponegoro, Semarang. 2010. 